American Journal of Applied Sciences 6 (5): 824-828, 2009

ISSN 1546-9239

(C) 2009 Science Publications

\title{
Organic Matter, Carbon and Humic Acids in Rehabilitated and Secondary Forest Soils
}

\author{
${ }^{1}$ Lee Yit Leng, ${ }^{1}$ Osumanu Haruna Ahmed, ${ }^{1}$ Nik Muhamad Ab. Majid and ${ }^{2}$ Mohamadu Boyie Jalloh \\ ${ }^{1}$ Department of Crop Science, Faculty of Agriculture and Food Science, \\ University Putra Malaysia Bintulu Campus, Sarawak, 97008 Bintulu, Sarawak, Malaysia \\ ${ }^{2}$ School of Sustainable Agriculture, \\ University Malaysia Sabah, Locked Bag 2073, 88999 Kota Kinabalu, Sabah, Malaysia
}

\begin{abstract}
Problem Statement: Tropical rainforests cover about 19.37 million ha (60\%) of Malaysia's total area and about 8.71 million ha can be found in Sarawak, Malaysia. Excessive logging, mining and shifting cultivation contribute to deforestation in Sarawak. The objectives of this study were to: (i) Quantify soil Organic Matter (SOM), Soil Organic Carbon (SOC) and Humic Acids (HA) in rehabilitated and secondary forest soils and (ii) Compare SOM, SOC and HA sequestrations of both forests. Approach: Soil samples were collected from a 16 year old rehabilitated forest and a secondary forest at Universiti Putra Malaysia, Bintulu Campus. Fifteen samples were taken at random with a soil auger at $0-20 \mathrm{~cm}$ and $20-40 \mathrm{~cm}$ depths. The bulk densities at these depths were determined by the coring method. The bulk density method was used to quantify the total C (TC), Total Organic Carbon (TOC), Organic Matter (OM), Humic Acids (HA) and total $\mathrm{N}$ at the stated sampling depths. Results: Regardless of forest soil type and depth, the amount of SOM of the two forests was similar. Except for $20-40 \mathrm{~cm}$ of the secondary forest soil whereby the quantity of total $\mathrm{C}$ sequestered was significantly lower than that of the rehabilitated forest soil, $\mathrm{C}$ sequestration was similar irrespective of forest type and depth. Nevertheless, stable C (organic carbon) sequestered in HA was generally higher in the rehabilitated forest soil compared with the secondary forest soil. This was attributed to higher yield of $\mathrm{HA}$ in the rehabilitated forest soil partly due to better humification at $20-40 \mathrm{~cm}$ in the rehabilitated forest soil. Conclusion: Hence, the findings suggest that organic $\mathrm{C}$ in HA realistically reflects $\mathrm{C}$ sequestration in the soils of the two forests investigated.
\end{abstract}

Key words: Secondary forest, rehabilitated forest, carbon sequestration, humic acids, soil organic matter, total carbon

\section{INTRODUCTION}

Soil Organic Carbon (SOC) pool contains an estimated $1500 \mathrm{Gt} \mathrm{C}$ or $80 \%$ of the total terrestrial C store. Moreover, it is the largest near-surface $\mathrm{C}$ stores on the earth ${ }^{[1]}$. Due to the enormous amount of $\mathrm{C}$ stored in Soil Organic Matter (SOM), it plays an essential role in the global $\mathrm{C}$ balance and affects global warming. Moreover, this dynamic nature of soil component exerts a dominant influence on many soil physical, chemical and biological properties. Tropical and subtropical forest soils account for around $30 \%$ of the total global SOM, but SOC storage capacity has been dramatically reduced to around $212 \mathrm{Mt} \mathrm{C}$ year $^{-1}$ by ongoing deforestation ${ }^{[2]}$.

Tropical rainforests cover about 19.37 million ha (60\%) of Malaysia's total area and about 8.71 million ha can be found in Sarawak, Malaysia. Excessive logging, mining and shifting cultivation contribute to deforestation in Sarawak. Generally, forests after being tempered with are left without proper silvicultural measures to stimulate development of valuable tree species for forest restoration. As a result, most of the disturbed forests are left to regenerate through natural processes. The total area of degraded and secondary forests is estimated to be 850 million hectares, corresponding to approximately $60 \%$ of the total area that is statistically classified as forests in the tropics (tropical Asia, tropical America and tropical Africa).

A rehabilitation programme initiated by Universiti Putra Malaysia (UPM), Malaysia and Japanese Center for International Studies in Ecology since 1990 has enabled establishment of indigenous tree species. Innoprise-Face Foundation Rainforest Rehabilitation 
Project (INFAPRO) for rehabilitation of logged forest sequestered atmospheric carbon dioxide $\left(\mathrm{CO}_{2}\right)$ by fast growing indigenous tree species on degraded soils. Tropical forest remains a viable resource for the economies of Malaysia, yet their potential as a $\mathrm{C}$ sink has received less attention ${ }^{[11]}$. Most studies have been focused on the $\mathrm{C}$ pools of forest floor and above-ground biomass. Soil acts as a sink of $\mathrm{C}$, by removing $\mathrm{CO}_{2}$ from the atmosphere through photosynthesis, leading to subsequent storage of organic $\mathrm{C}$ through plant and microbial biomass and also remains as soil humus. It is estimated that the total global terrestrial biomass is almost as large as the atmospheric $\mathrm{C}$ pool. However, soil $\mathrm{C}$ stock is about equal to the sum of these two major C stocks, with its magnitude depending on the considered soil depth.

At the moment we do not know important environmental indicators such as the mechanism of soil $\mathrm{C}$ sequestration and humic substances (e.g., Humic Acids (HA) accumulation in the afforested soils of the project at UPM. This is essential because SOC, the main form of sequestered $\mathrm{C}$ in the soil, relates to the proportion of Net Primary Productivity (NPP) returned to the soil. Among the processes that lead to SOC sequestration are conversion of biomass into humus, aggregation to prevent $\mathrm{C}$ oxidation and translocation of $\mathrm{C}$ into sub soil. Although well established and managed indigenous trees have a potential in $\mathrm{C}$ sequestration in biomass, the importance and mechanisms of $\mathrm{C}$ sequestration in soils on which these trees are grown are inadequately understood, partly because changes in C content, humic substances [(humic substances comprised about $60-80 \%$ of the $\left.\mathrm{SOM})^{[3]}\right]$ and bulk density to a minimum depth of $1 \mathrm{~m}$ are seldom measured in soils; as a result, few attempts have been made to measure or model temporal changes in the SOC pool.

The objectives of this study were to: (i) Quantify SOM, SOC and HA in rehabilitated and secondary forest soils and (ii) Compare SOM, SOC and HA sequestrations of these forest soils.

\section{MATERIALS AND METHODS}

Soil samples were collected from a 16 year old rehabilitated forest and a secondary forest at Universiti Putra Malaysia, Bintulu Campus. The abandoned shifting cultivation area was rehabilitated since 1991 by planting indigenous timber species to identify suitable species and appropriate techniques to rehabilitate the degraded forest area. The size of each experimental plot was 1.0 ha. Fifteen samples were taken at random with a soil auger at $0-20 \mathrm{~cm}$ and $20-40 \mathrm{~cm}$ depths. The bulk densities at these depths were determined by the coring method. The bulk density method was used to quantify the total C (TC), Total Organic Carbon (TOC), Organic Matter (OM), Humic Acids (HA) and total $\mathrm{N}$ at the stated sampling depths.

Soil samples were air dried, sieved to pass a $2 \mathrm{~mm}$ sieve and were kept in air tight plastic vials. The hydrometer method was used to determine soil texture. The method described by Chefetz et al. ${ }^{[4]}$ was used to determine TC, SOM and TOC. Soil total N was determined using micro-Kjeldahl method. The soil $\mathrm{pH}$ was determined in a 1:2.5 of soil:distilled water suspension and/or $1 \mathrm{M} \mathrm{KCl} \mathrm{using} \mathrm{a} \mathrm{glass} \mathrm{electrode.}$

The extraction of HA was done using standard procedures with some modifications. Ten grams (dry weight basis) of soil samples (at natural moisture level) were placed in polyethylene centrifuge bottles, $100 \mathrm{~mL}$ of $0.1 \mathrm{M} \mathrm{NaOH}$ solution was added and the bottles were tightly closed with a rubber stopper ${ }^{[5]}$. The samples were equilibrated at room temperature (about $25^{\circ} \mathrm{C}$ ) on a reciprocal mechanical shaker at $180 \mathrm{rpm}$ for $12 \mathrm{~h}$. At the end of extraction period, the side of the bottle was washed with distilled water and the mixture centrifuged at $16,000 \mathrm{G}$ for $15 \mathrm{~min}$. The dark coloured supernatant liquors containing the HA were decanted, filtered through glass-wool and the $\mathrm{pH}$ of the solutions was adjusted to 1.0 with $6 \mathrm{M}$ HCL. The HA were allowed to stand or equilibrate at room temperature for $12 \mathrm{~h}$.

The fractionation time used immediately after acidification was $12 \mathrm{~h}$. At the end of equilibration, the supernatant liquors (fulvic acids) were siphoned off from the acidified extract. The remainder of the suspensions was transferred to polyethylene bottles and the HA were centrifuged off. The method described by Ahmed et $a l^{[6]}$ was used with modifications to purify the HA. The HA were purified by being suspending them in $100 \mathrm{~mL}$ distilled water (excess distilled water can serve as Bronsted-Lowry acid), centrifuged at $16,000 \mathrm{G}$ for $10 \mathrm{~min}$ and the supernatant decanted. The washed $\mathrm{HA}$ were oven dried at $50^{\circ} \mathrm{C}$ to a constant weight. The yield of HA was expressed as percentage (\%) of the weight of soil used. Functional group analysis was conducted by the method described by Inbar et al. ${ }^{[7]}$. Level of humification of $\mathrm{HA}$ was determined by $E_{4} / E_{6}$ method using spectroscopy. The model of the spectrometer used was Lambda 25 UV/VIS (Shelton, CT, USA).

Independent $\mathrm{T}$-test was used to detect significant difference between SOM, TOC, TC, HA yield, N and $\mathrm{pH}$ of rehabilitated and secondary forest soils. Statistical Analysis System (SAS) version 9.1 was used for the statistical analysis. 
Am. J. Applied Sci., 6 (5): 824-828, 2009

\section{RESULTS}

The $\mathrm{pHs}$ of both forest soils regardless of depth were typical of Ultisols (Table 1). There was significant difference between the $\mathrm{pH}(1 \mathrm{M} \mathrm{KCl})$ of the rehabilitated and secondary forest soils at $0-20$ and 20$40 \mathrm{~cm}$ depths.

The soil texture of the rehabilitated forest at $0-20$ and $20-40 \mathrm{~cm}$ was clay loam. However, the soil texture of the secondary forest at the aforestated depths was sandy clay loam (Table 2). This suggests that the soils of the two forests are typical of Nyalau Series ((Typic Tualemkuts), a series which is characterized by sandy loam in the top soil and sandy clay loam in the subsoil. The soil bulk densities (Table 2) at the two depths of both forests were found to be within the range reported elsewhere.

Irrespective of forest type and depth, there was no significant difference in the percentages and quantities of SOM of the two forests (Table 3). These values were relatively similar to those reported elsewhere ${ }^{[8]}$.

There was no significant difference in the $20-40 \mathrm{~cm}$ (Table 4). In both forest soils, the TC quantity in the top soil was not significantly different from that of the subsoil. However, the quantity of TC in $20-40 \mathrm{~cm}$ depth of the rehabilitated forest was higher that of the secondary forest (Table 4).

Table 1: $\mathrm{pH}$ of rehabilitated and secondary forest soils

\begin{tabular}{lll}
\hline Forest type & $\mathrm{pH}(1 \mathrm{M} \mathrm{KCl})$ & $\mathrm{pH}($ Water $)$ \\
\hline $\begin{array}{l}\text { Rehabilitated forest } \\
(0-20 \mathrm{~cm})\end{array}$ & $3.505 \pm 0.024^{\mathrm{a}}$ & $4.209 \pm 0.040^{\mathrm{a}}$ \\
$\quad(20-40 \mathrm{~cm})$ & $3.599 \pm 0.025^{\mathrm{b}}$ & $4.275 \pm 0.030^{\mathrm{a}}$ \\
$\begin{array}{l}\text { Secondary forest } \\
\quad(0-20 \mathrm{~cm})\end{array}$ & $3.468 \pm 0.03^{\mathrm{a}}$ & $4.147 \pm 0.044^{\mathrm{a}}$ \\
$\quad(20-40 \mathrm{~cm})$ & $3.571 \pm 0.018^{\mathrm{b}}$ & $4.238 \pm 0.033^{\mathrm{a}}$ \\
$\begin{array}{l}\text { Forest type (0-20 cm) } \\
\quad \text { Rehabilitated forest }\end{array}$ & $3.505 \pm 0.024^{\mathrm{a}}$ & $4.209 \pm 0.042^{\mathrm{a}}$ \\
$\quad \begin{array}{l}\text { Secondary forest } \\
\text { Forest type (20-40 cm) }\end{array}$ & $3.468 \pm 0.034^{\mathrm{a}}$ & $4.147 \pm 0.044^{\mathrm{a}}$ \\
$\quad$ Rehabilitated forest & $3.599 \pm 0.025^{\mathrm{a}}$ & $4.275 \pm 0.030^{\mathrm{a}}$ \\
$\quad$ Secondary forest & $3.571 \pm 0.018^{\mathrm{a}}$ & $4.238 \pm 0.033^{\mathrm{a}}$ \\
\hline $\begin{array}{l}\text { Note: Means within column with different letter(s) indicate } \\
\text { significant difference between soil depths and forest types by } \\
\text { independent t-test at p } \leq 0.05\end{array}$ &
\end{tabular}
percentages of total $\mathrm{C}$ of both forest soils at $0-20$ and

The soil total $\mathrm{N}$ of the rehabilitated and secondary forests significantly decreased down the soil profile (Table 5) and this observation was consistent with the general observation that soil $\mathrm{N}$ decreases with increasing soil depth because of decrease in organic N.

Table 2: Soil textures and bulk densities of rehabilitated and secondary forest soils

\begin{tabular}{|c|c|c|}
\hline Forest type & Texture & Bulk density $\left(\mathrm{g} \mathrm{m}^{-3}\right)$ \\
\hline \multicolumn{3}{|l|}{ Rehabilitated forest } \\
\hline$(0-20 \mathrm{~cm})$ & Clay loam & $1.175 \pm 0.012^{\mathrm{a}}$ \\
\hline$(20-40 \mathrm{~cm})$ & Clay loam & $1.230 \pm 0.011^{\mathrm{b}}$ \\
\hline \multicolumn{3}{|l|}{ Secondary forest } \\
\hline$(0-20 \mathrm{~cm})$ & Sandy clay loam & $1.129 \pm 0.035^{\mathrm{a}}$ \\
\hline$(20-40 \mathrm{~cm})$ & Sandy clay loam & $1.212 \pm 0.008^{b}$ \\
\hline \multicolumn{3}{|l|}{ Forest type $(0-20 \mathrm{~cm})$} \\
\hline Ehabilitated forest & - & $1.175 \pm 0.012^{\mathrm{a}}$ \\
\hline Secondary forest & - & $1.129 \pm 0.035^{\mathrm{a}}$ \\
\hline \multicolumn{3}{|l|}{ Forest type $(20-40 \mathrm{~cm})$} \\
\hline Rehabilitated forest & - & $1.230 \pm 0.011^{\mathrm{a}}$ \\
\hline Secondary forest & - & $1.212 \pm 0.008^{\mathrm{a}}$ \\
\hline
\end{tabular}

Note: Means within column with different letter(s) indicate significant difference between soil depths and forest types by independent t-test at $\mathrm{p} \leq 0.05$

Table 3: Soil organic matter (\%) and corresponding quantities $\left(\mathrm{Mg} \mathrm{ha}^{-1}\right)$ in rehabilitated and secondary forest soils

\begin{tabular}{llc}
\hline $\begin{array}{l}\text { Forest } \\
\text { type }\end{array}$ & $\begin{array}{l}\text { Soil organic } \\
\text { matter }(\%)\end{array}$ & $\begin{array}{l}\text { Organic matter } \\
\text { quantity }\left(\mathrm{Mg} \mathrm{ha}^{-1}\right)\end{array}$ \\
\hline $\begin{array}{l}\text { Rehabilitated forest } \\
(0-20 \mathrm{~cm})\end{array}$ & $6.908 \pm 0.305^{\mathrm{a}}$ & $121.750 \pm 5.374^{\mathrm{a}}$ \\
$\quad(20-40 \mathrm{~cm})$ & $6.869 \pm 0.335^{\mathrm{a}}$ & $126.740 \pm 6.173^{\mathrm{a}}$ \\
$\begin{array}{l}\text { Secondary forest } \\
(0-20 \mathrm{~cm})\end{array}$ & $6.419 \pm 0.286^{\mathrm{a}}$ & $108.700 \pm 4.843^{\mathrm{a}}$ \\
$(20-40 \mathrm{~cm})$ & $6.028 \pm 0.315^{\mathrm{a}}$ & $109.590^{\mathrm{a}} \pm 5.717^{\mathrm{a}}$ \\
Forest type (0-20 cm) & & \\
$\quad \begin{array}{l}\text { Rehabilitated forest } \\
\text { Secondary forest }\end{array}$ & $6.908 \pm 0.305^{\mathrm{a}}$ & $121.750 \pm 5.374^{\mathrm{a}}$ \\
Forest type (20-40 cm) & $6.419 \pm 0.286^{\mathrm{a}}$ & $108.700 \pm 4.843^{\mathrm{a}}$ \\
$\quad \begin{array}{l}\text { Rehabilitated Forest } \\
\text { Secondary forest }\end{array}$ & $6.869 \pm 0.335^{\mathrm{a}}$ & $126.740 \pm 6.173^{\mathrm{a}}$ \\
\hline $\begin{array}{l}\text { Note: Means within column with different letter(s) indicate } \\
\text { significant difference between soil depths and forest types by } \\
\text { independent t-test at } \mathrm{p} \leq 0.05\end{array}$
\end{tabular}

Table 4: Total carbon (\%), quantity of carbon $\left(\mathrm{Mg} \mathrm{ha}^{-1}\right)$, carbon (\%) in HA and quantity of stable carbon $\left(\mathrm{Mg} \mathrm{ha}^{-1}\right)$, in HA in rehabilitated and secondary forest soils

\begin{tabular}{lllll}
\hline Forest type & Total carbon (\%) & Quantity of carbon $\left(\mathrm{Mg} \mathrm{ha}^{-1}\right)$ & $\%$ Carbon in HA & Stable carbon in HA $\left.(\mathrm{Mg} \mathrm{ha})^{-1}\right)$ \\
\hline $\begin{array}{l}\text { Rehabilitated forest } \\
\quad(0-20 \mathrm{~cm})\end{array}$ & $4.007 \pm 0.177^{\mathrm{a}}$ & $70.616 \pm 3.117^{\mathrm{a}}$ & 29.29 & $6.436 \pm 0.483^{\mathrm{a}}$ \\
$\quad(20-40 \mathrm{~cm})$ & $3.987 \pm 0.194^{\mathrm{a}}$ & $73.568 \pm 3.573^{\mathrm{a}}$ & 28.71 & $5.050 \pm 0.423^{\mathrm{b}}$ \\
$\begin{array}{l}\text { Secondary forest } \\
\quad(0-20 \mathrm{~cm})\end{array}$ & $3.723 \pm 0.166^{\mathrm{a}}$ & $63.048 \pm 2.809^{\mathrm{a}}$ & 33.06 & $4.470 \pm 0.484^{\mathrm{a}}$ \\
$\quad(20-40 \mathrm{~cm})$ & $3.496 \pm 0.182^{\mathrm{a}}$ & $63.558 \pm 3.315^{\mathrm{a}}$ & 28.71 & $3.236 \pm 0.520^{\mathrm{a}}$ \\
$\begin{array}{l}\text { Forest type (0-20 cm) } \\
\quad \text { Rehabilitated forest }\end{array}$ & $3.977 \pm 0.185^{\mathrm{a}}$ & $70.616 \pm 3.117^{\mathrm{a}}$ & - & $6.436 \pm 0.483^{\mathrm{a}}$ \\
$\quad \begin{array}{l}\text { Secondary forest } \\
\text { Forest type (20-40 cm) }\end{array}$ & $3.723 \pm 0.166^{\mathrm{a}}$ & $63.048 \pm 2.809^{\mathrm{a}}$ & - & $4.470 \pm 0.484^{\mathrm{b}}$ \\
$\quad$ Rehabilitated forest & $3.987 \pm 0.194^{\mathrm{a}}$ & $73.568 \pm 3.573^{\mathrm{a}}$ & - & $5.050 \pm 0.423^{\mathrm{a}}$ \\
$\quad$ Secondary forest & $3.496 \pm 0.182^{\mathrm{a}}$ & $63.558 \pm 3.315^{\mathrm{b}}$ & - & $3.236 \pm 0.520^{\mathrm{b}}$ \\
\hline
\end{tabular}

Note: Means within column with different letter(s) indicate significant difference between soil depths and forest types by independent t-test at $\mathrm{p} \leq 0.05$ 
Am. J. Applied Sci., 6 (5): 824-828, 2009

Table 5: Total $\mathrm{N}$ and $\mathrm{C} / \mathrm{N}$ ratios of rehabilitated and secondary forest

\begin{tabular}{|c|c|c|}
\hline Forest type & Total N (\%) & $\mathrm{C} / \mathrm{N}$ ratio \\
\hline \multicolumn{3}{|l|}{ Rehabilitated forest } \\
\hline$(0-20 \mathrm{~cm})$ & $0.205 \pm 0.014^{\mathrm{a}}$ & $20.455 \pm 1.216^{\mathrm{a}}$ \\
\hline$(20-40 \mathrm{~cm})$ & $0.140 \pm 0.007^{b}$ & $29.424 \pm 1.914^{\mathrm{b}}$ \\
\hline \multicolumn{3}{|l|}{ Secondary forest } \\
\hline$(0-20 \mathrm{~cm})$ & $0.163 \pm 0.015^{\mathrm{a}}$ & $25.229 \pm 2.250^{\mathrm{a}}$ \\
\hline$(20-40 \mathrm{~cm})$ & $0.098 \pm 0.009^{b}$ & $38.729 \pm 2.987^{b}$ \\
\hline \multicolumn{3}{|l|}{ Forest type (0-20 cm) } \\
\hline Rehabilitated Forest & $0.205 \pm 0.014^{\mathrm{a}}$ & $20.455 \pm 1.216^{\mathrm{a}}$ \\
\hline Secondary Forest & $0.163 \pm 0.015^{\mathrm{a}}$ & $25.229 \pm 2.250^{\mathrm{a}}$ \\
\hline \multicolumn{3}{|l|}{ Forest type $(20-40 \mathrm{~cm})$} \\
\hline Rehabilitated Forest & $0.140 \pm 0.007^{\mathrm{a}}$ & $29.424 \pm 1.914^{\mathrm{a}}$ \\
\hline Secondary Forest & $0.098 \pm 0.009^{\mathrm{b}}$ & $38.729 \pm 2.987^{b}$ \\
\hline
\end{tabular}

Table 6: Humic acids yields (\%) and corresponding quantities (Mg $\mathrm{ha}^{-1}$ ) in rehabilitated and secondary forest soils

\begin{tabular}{|c|c|c|}
\hline $\begin{array}{l}\text { Forest } \\
\text { type }\end{array}$ & $\begin{array}{l}\text { HA yields } \\
(\%)\end{array}$ & $\begin{array}{l}\text { Quantities of HA } \\
\left(\mathrm{Mg} \mathrm{ha}^{-1}\right)\end{array}$ \\
\hline \multicolumn{3}{|l|}{ Rehabilitated forest } \\
\hline$(0-20 \mathrm{~cm})$ & $1.247 \pm 0.094^{\mathrm{a}}$ & $21.973 \pm 1.649^{\mathrm{a}}$ \\
\hline$(20-40 \mathrm{~cm})$ & $0.953 \pm 0.080^{\mathrm{b}}$ & $17.589 \pm 1.472^{\mathrm{a}}$ \\
\hline \multicolumn{3}{|l|}{ Secondary forest } \\
\hline$(0-20 \mathrm{~cm})$ & $0.787 \pm 0.089^{\mathrm{a}}$ & $13.322 \pm 1.514^{\mathrm{a}}$ \\
\hline$(20-40 \mathrm{~cm})$ & $0.620 \pm 0.100^{\mathrm{a}}$ & $11.272 \pm 1.811^{\mathrm{a}}$ \\
\hline \multicolumn{3}{|l|}{ Forest type $(0-20 \mathrm{~cm})$} \\
\hline Rehabilitated forest & $1.247 \pm 0.094^{\mathrm{a}}$ & $21.973 \pm 1.649^{\mathrm{a}}$ \\
\hline Secondary forest & $0.787 \pm 0.089^{b}$ & $13.322 \pm 1.514^{\mathrm{b}}$ \\
\hline \multicolumn{3}{|l|}{ Forest type $(20-40 \mathrm{~cm})$} \\
\hline Rehabilitated forest & $0.953 \pm 0.080^{\mathrm{a}}$ & $17.589 \pm 1.472^{\mathrm{a}}$ \\
\hline Secondary forest & $0.620 \pm 0.010^{\mathrm{b}}$ & $11.272 \pm 1.811^{\mathrm{b}}$ \\
\hline
\end{tabular}

The percentages of HA yields and corresponding quantities in $\mathrm{Mg} \mathrm{ha}^{-1}$ of the rehabilitated at 0-20 and 20$40 \mathrm{~cm}$ depth were not statistically different. Similar observation was made for the secondary forest (Table 6). However, the percent yield of HA and the quantity of $\mathrm{HA}$ in $\mathrm{Mg} \mathrm{ha}^{-1}$ at $0-20$ and $20-40 \mathrm{~cm}$ of the rehabilitated forest soil were significantly greater than those of the secondary forest soil (Table 6). This finding was probably because of lack of $\mathrm{N}$ for efficient conversion of biomass $\mathrm{C}$ into humus $\mathrm{C}$ in the secondary forest soils which is much required by the humification of biomass returned to soil (through litter and roots).

There was significant difference in the quantities of stable $\mathrm{C}$ of both forest soils at $0-20$ and $20-40 \mathrm{~cm}$, except for secondary forest at the two depths. The quantity of stable $\mathrm{C}$ depends on amount of HA. Since the $\mathrm{C}$ in $\mathrm{HA}$ are more stable, it is more realistic to quantify the amount of $\mathrm{C}$ sequestered in forest soils.

The $\mathrm{E}_{4} / \mathrm{E}_{6}$ ratios at $0-20$ and $20-40 \mathrm{~cm}$ of the rehabilitated forest soil were 6.382 and 6.599 respectively, while those of the secondary forest soil at the stated depths were 6.144 and 6.747 , respectively (Table 7). This indicates prominence of aliphatic compounds of HA or relatively low molecular weight ${ }^{[9]}$.

Except for the total acidity of the secondary forest, the $\mathrm{E}_{4} / \mathrm{E}_{6}$, carboxylic-COOH, phenolic-OH and total acidity of rehabilitated and secondary forest soils (Table 7) were found to be consistent with the ranges reported elsewhere ${ }^{[10]}$. Higher carboxylic group in HA of the secondary forest soils contributed to higher acidity, probably due to inclusion of amides and esters in the analysis by spectroscopy.

\section{DISCUSSION}

The higher $\mathrm{pH}(1 \mathrm{M} \mathrm{KCl})$ values at $20-40 \mathrm{~cm}$ than those of $0-20 \mathrm{~cm}$ of the two forests (Table 1) could be attributed to leaching of basic cations from $0-20$ to 20 $40 \mathrm{~cm}$. However, no such observation was made for $\mathrm{pH}$ (water). This may be because the $\mathrm{KCl}$ used was more effective in displacing hydrogen ions. The general absence of significant difference between the soil $\mathrm{pH}$ of the rehabilitated and secondary forests regardless of soil depth suggests that forest type had no significant effect on the soil $\mathrm{pH}$.

Even though the soil textures of both forests were different, the soil bulk densities of these forests significantly increased down the soil profile. This observation also suggests that regardless of forest type, the soils get compacted down their profiles. Perhaps some of clay in the top soil may have been eluviated vertically and deposited in the subsoil. The absence of significant difference in the soil bulk densities of the rehabilitated and secondary forests irrespective of depth could be partly associated with no significant difference in the SOM of the two forests at both $0-20$ and 20-40 $\mathrm{cm}$ (Table 3). The similar quantities of SOM irrespective of forest type and depth, suggests that SOM in the rehabilitated forest might have reached equilibrium.

The soil total $\mathrm{N}$ regardless of depth and type of forest were typical of Ultisol. The significant accumulation of $\mathrm{N}$ at $20-40 \mathrm{~cm}$ in the rehabilitated forest soil compared to that of the secondary forest could be attributed to the difference in soil texture. It was possible that the $\mathrm{N}$ leached from $0-20 \mathrm{~cm}$ got accumulated in $20-40 \mathrm{~cm}$ of the rehabilitated forest (clay loam) while in the case of secondary forest (sandy clay loam), it may have been leached out of the soil profile. 
Am. J. Applied Sci., 6 (5): 824-828, 2009

Table 7: $\mathrm{E}_{4} / \mathrm{E}_{6}$ ratios, carboxylic- $\mathrm{COOH}$, phenolic-OH and total acidity of rehabilitated and secondary forest soils

\begin{tabular}{|c|c|c|c|c|c|c|c|c|}
\hline Forest type & $\mathrm{E}_{4} / \mathrm{E}_{6}$ ratios & Range & Carboxylic $-\mathrm{COOH}$ & Range & Phenolic $-\mathrm{OH}$ & Range & Total acidity & Range \\
\hline $\begin{array}{l}\text { Rehabilitated forest } \\
\quad(0-20 \mathrm{~cm})\end{array}$ & 6.382 & $3-5$ & 363 & $150-570$ & 300 & $210-570$ & 663 & $560-890$ \\
\hline $\begin{array}{c}(20-40 \mathrm{~cm}) \\
\text { Secondary forest }\end{array}$ & 6.599 & & 500 & & 300 & & 800 & \\
\hline $\begin{array}{l}(0-20 \mathrm{~cm}) \\
(20-40 \mathrm{~cm})\end{array}$ & $\begin{array}{l}6.144 \\
6.747\end{array}$ & & $\begin{array}{l}600 \\
588\end{array}$ & & $\begin{array}{l}550 \\
550\end{array}$ & & $\begin{array}{l}1150 \\
1137\end{array}$ & \\
\hline
\end{tabular}

$\operatorname{Tan}^{[9]}$, Schnitzer ${ }^{[10]}$

The increase in $\mathrm{C} / \mathrm{N}$ ratio with increasing soil depth in both forests suggests that there was more humification at $0-20 \mathrm{~cm}$ than in $20-40 \mathrm{~cm}$. Although the degree of humification at $0-20 \mathrm{~cm}$ was observed to be statistically similar for both forest soils, the significant difference observed in the $\mathrm{C} / \mathrm{N}$ ratios of the of the rehabi rehabilitated and secondary forest soils at 20-40 $\mathrm{cm}$ may not necessarily suggest differences in humification levels. The lower $\mathrm{C} / \mathrm{N}$ ratio of the rehabilitated forest compared with that of the secondary forest could be due to the significant accumulation of $\mathrm{N}$ at $20-40 \mathrm{~cm}$ as discussed previously.

The SOM and TC sequestered in the rehabilitated and secondary forest soils were similar but the TC sequestered by HA was significantly higher in the rehabilitated forest soil compared to the secondary forest soil irrespective of depth. Hence, the finding suggest that the stability of $\mathrm{C}$ in $\mathrm{HA}$ realistically reflects $\mathrm{C}$ sequestration in this study.

\section{CONCLUSION}

The SOM and TC sequestered in the rehabilitated and secondary forest soils were similar but the TC sequestered by HA was significantly higher in the rehabilitated forest soil compared to the secondary forest soil irrespective of depth. Hence, the finding suggest that the stability of $\mathrm{C}$ in HA realistically reflects $\mathrm{C}$ sequestration in this study. This is partly because the quantity of stable $\mathrm{C}$ depends on the amount of HA.

\section{ACKNOWLEDGMENT}

The authors acknowledge the financial support (Fundamental Research Scheme) received from the Ministry of Higher Education, Malaysia via Universiti Putra Malaysia.

\section{REFERENCES}

1. Amundson, R., 2001. The Carbon Budget in Soils. Ann. Rev. Earth Planet. Sci., 29: 535-562. DOI: 10.1146/annurev.earth.29.1.535.
2. Mayaux, P., P. Holmgren, F. Achard, H. Eva, H. Stibig and A. Branthomme, 2005. Tropical forest cover change in the 1990s and options for future monitoring. Philosophical Transactions Royal Soc. London B., 360: 373-384. DOI: 10.1098/rstb.2004.1590.

3. Fan, S.M., S.C. Wofsy, P.S. Bakwin and D.J. Jacob, 1990. Atmosphere-biosphere exchange of $\mathrm{CO}_{2}$ and $\mathrm{O}_{3}$ in the central Amazon forest. J. Geophys. Res., 95: 16851-16864. http:/www. agu.org/pubs/crossref/1990/90JD00595.shtml.

4. Chefetz, B., P.G. Hatcher, Y. Hadar and Y. Chen, 1996. Chemical and biological characterization of organic matter during composting of municipal solid waste. J. Exp. Qual., 25: 776-785. http://jeq.scijournals.org/cgi/reprint/25/4/776.

5. Gracia, D., J. Cegarra, M.P. Bernal and A. Navarro, 1993. Comparative evaluation of methods employing alkali and sodium pyrophosphate to extract humic subtances from peat. Commun. Soil Sci. Plant Anal., 24: 1481-1494. DOI: 10.1080/00103629309368893.

6. Ahmed, O.H., M.H.A. Husni, A.R. Anuar, M.M. Hanafi and E.D.S. Angela, 2004. A modified way of producing humic acid from composted pineapple leaves. J. Sustainable Agric., 25: 129-139. DOI: 10.1300/J064v25n01_10.

7. Inbar, Y., Y. Chen and Y. Hadar, 1990. Humic substances formed during the composting of organic matter. Soil Sci. Soc. Am J., 54: 1316-1323. http://soil.scijournals.org/ cgi/content/abstract/54/5/1316.

8. Anderson, J.M., 1991. The effects of climate change on decomposition process in grassland and coniferous forests. Ecolog. Appl., 1: 326-347. DOI: $10.2307 / 1941761$.

9. Tan, K.H., 2003. Humic Matter in Soil and the Environment: Principles and Controversies. 1st ed. Marcel Dekker, Inc., New York, ISBN: 978-08247-4272-0, pp: 385.

10. Schnitzer, M. and C.M. Preston, 1986. Analysis of humic acids by solution and solid- state carbon-13 nuclear magnetic resonance. Soil Sci. Soc. Am. J., 50: 326-331. http://soil.scijournals.org/ cgi/content/abstract/50/2/326. 